\title{
Impact of Demerger on Shareholders' Wealth
}

\author{
Dr. Ranjit Singh, \\ Lecturer, Department of Business Administration, \\ Assam University (A Central University), Silchar, \\ Email: look_for_ranjit@yahoo.co.in \\ Phone: +91-94357 35868 \\ Dr. Amalesh Bhowal, \\ Professor, Department of Commerce, \\ Assam University, (A Central University), Silchar \\ Diphu Campus, Assam \\ E-Mail: amalesh_b1@rediffmail.com \\ Phone: +91-94353-91536 \\ Mr. Varun Bawari \\ Manager, \\ M.L.Pharma \\ Dibrugarh-786001 \\ Email: varunbawari@yahoo.com \\ Phone: +91-9435031179
}

\begin{abstract}
The purpose of this paper is to investigate the change in the level of the wealth of the shareholders' before the demerger and after the demerger. In the present study the data relating to share prices has been taken from the official website of Bombay Stock Exchange. Here the average of the six months price of the demerged company before demerger and average six months price or the average price upto $31^{\text {st }}$ of July, 2007 has been collected of demerged and resultant company after demerger. It is found that after demerger there is increase in the total wealth of the shareholders in almost all the cases. Given the nature of the study, generalizations cannot be made as the study is conducted in a bullish market. The time specific character of the subject matter is an opportunity for future longitudinal research. The practical implications of this paper are that presently de-mergers creating enormous wealth
\end{abstract}


for shareholders. It is because of the negative synergy. Due to the demerger this negative synergy is removed and the value is unlocked. However, Investors should differentiate between genuine attempts at value creation and de-mergers undertaken to create hype around the stocks. Stay away from dubious companies that want to manipulate prices. Investors should focus on the quality of management and corporate governance record of the company.

Keywords: Demerger, Demerged Company, Resultant Company, Negative Synergy, Shareholders Wealth 


\subsection{Demerger or Spin-Off}

Demergers were an American invention of the 1920s and became common since the 1950s. Corporate demerger is one of several ways through which a firm may divest a division and improve its focus. A demerger is a pro-rata distribution of the shares of a firm's subsidiary to the shareholders of the firm. There is neither a dilution of equity nor a transfer of ownership from the current shareholders. After the distribution, the operations and management of the subsidiary are separated from those of the parent. Demerger constitutes a unique mode of divesting assets since they do not involve any cash transactions. Thus, they cannot be motivated by a desire to generate cash to pay off debt, as is often the case with other modes of divestitures. In American English this process is termed spin-off, in British English, demerger.

A De-merger results in the transfer by a company of one or more of its undertakings to another company. The company whose undertaking is transferred is called the De-merged company and the company (or the companies) to which the undertaking is transferred is referred to as the Resulting company. Demerger Companies often have to downsize or 'contract' their operations in certain circumstances such as when a division of the company is performing poorly or simply because it no longer fits into the company's plans or give effect to rationalization or specialization in the manufacturing process. This may also be necessary to undo a previous merger or acquisition which proved unsuccessful. This type of restructuring can take various forms such as demergers or spin offs, split offs, etc. Large entities sometimes hinder entrepreneurial initiative, sideline core activities, reduce accountability and promote investment in non-core activities. There is an increasing realization among companies that demerger may allow them to strengthen their core competence and realize the true value of their business.

After the drive down the mergers and acquisitions avenue, India Incorporations has turned into the road of de-mergers as it speeds towards corporate restructuring. Be it the Birla group's decision to break up Indo Gulf Corporation into the fertilizer and copper businesses, or L\&T hiving off its cement division, spin-offs have emerged as key vehicles for corporate regimes. Spin-offs, which essentially break up a company into two or more parts, strive to attain better focus or a better valuation for parts of the business which tended to be neglected in a conglomerate structure.

\subsection{Demerger Legislation in India}

The term "Demerger" has not been defined in the Companies Act, 1956. However, it has been defined in Sub-section (19AA) of Section 2 of the Income-tax Act, 1961. According to the said Sub-section, "demerger" in relation to companies, means transfer, pursuant to a scheme of arrangement under Sections 391 to 394 of the Companies Act, 1956, by a demerged company of its one or more undertakings to any resulting company in such a manner that - 


\section{Ml Macrothink}

i. All the property of the undertaking being transferred by the demerged company, immediately before the demerger, becomes the property of the resulting company

ii. All the liabilities relatable to the undertaking, being transferred by the demerged company, immediately before the demerger, become the liabilities of resulting company of virtue of the demerger.

iii. The property and the liabilities of the undertaking, being transferred by the demerged company are transferred at values appearing in its books of account immediately before the demerger;

iv. The resulting company issues, in consideration of the demerger, its shares to the shareholders of the demerged company on a proportionate basis;

v. The shareholders holding not less than three fourths in value of the share in the demerged company (other than shares already held therein immediately before the demerger or by a nominee for, the resulting company or, its subsidiary) become shareholders of the resulting company or companies by virtue of the demerger,

vi. The transfer of the undertaking is on a going concern basis;

vii. The demerger is in accordance with the conditions, if any, notified under Sub section (5) of Section 72A of the Income Tax Act 1961 by the Central Government in this behalf.

Explanation 1- For the purposes of this clause, "undertaking" shall include any, part of an undertaking, or a unit or division of an undertaking or a business activity taken as a whole, but does not include individual assets or liabilities or any combination thereof not constituting a business activity.

Explanation 2 - For the purposes of this clause, the liabilities referred to in sub-clause (ii), shall include:

a. The liabilities which arise out of the activities or operations of the undertaking;

b. The specific loans or borrowings (including debentures) raised, incurred and utilized solely for the activities or operations of the undertaking; and

c. In cases, other than those referred to in clause (a) or clause (b), so much of the amounts of general or multipurpose borrowings, if any, of the demerged company as stand in the same proportion which the value of the assets transferred in a demerger bears to the total value of the assets of such demerged company immediately before the demerger.

Explanation 3 - For determining the value of the property referred to in sub-clause (iii), any change in the value of assets consequent to their revaluation shall be ignored.

Explanation 4 - For the purposes of this clause, the splitting up or the reconstruction of any authority or a body constituted or established under a Central, State or Provincial Act, or a local authority or a public sector company, into separate authorities or bodies or local authorities or companies, as the case may be, shall be deemed to be a demerger if such split 
up or reconstruction fulfills such conditions as may be notified in the Official Gazette, by the Central Government.

From the above, the following points emerge about demergers:

1.Demerger is essentially a scheme of arrangement under Section 391 to 394 of the Companies Act, 1956 requiring approval by:

ii. Majority of shareholders holding shares representing three-fourths value in meeting convened for the purpose; and

iii. Sanction of High Court.

2.Demerger involves 'transfer' of one or more 'undertakings'.

3.The transfer of 'undertakings' is by the demerged company, which is otherwise known

as transferor company. The company to which the undertaking is transferred is known as resulting company which is otherwise known as 'transferee company'.

Demerged Company According to Sub-section (19AAA) of Section 2 of the Income-tax Act, 1961, "demerged company" means the company whose undertaking is transferred, pursuant to a demerger, to a resulting company. Resulting Company According to Sub-section (41A) of Section 2 of the Income-tax Act, 1961 "resulting company" means one or more companies (including a wholly owned subsidiary thereof) to which the undertaking of the demerged company is transferred in a demerger and, the resulting company in consideration of such transfer of undertaking, issues shares to the shareholders of the demerged company and includes any authority or body or local authority or public sector company or a company established, constituted or formed as a result of demerger. The definition of 'resulting company' has clearly brought out three important requirements while establishing its relationship with demerging company. They are -

i. Consideration for transfer of undertaking would be by issue of shares only, by resulting company.

ii. Such consideration would be paid only to the shareholders of demerged company.

iii. Resulting company can also be a subsidiary company of a demerged company.

\subsection{Mode of Demerger}

Demerger is carried on under the scheme of arrangement with approval of the court U/s 391 of the Companies Act.

\subsection{Procedure for Demerger}

The following procedures are adopted in case of demergers:

1. Demerger forms part of the scheme of arrangement or compromise within the ambit of Section 390, 391, 392, 393, 394 besides Sec 394A

2. Demerger is most likely to attract the other provisions of the companies Act, 
envisaging reduction of Share capital comprising Sec. 100 to 105

3. The company is required to pass a special resolution which is subject to the confirmation by the court by making an application.

4. The notice to the shareholders convening the meeting for the approval will usually consist of the following detail:

(a) Full Details of the scheme

(b) Effect of the scheme on shareholders, creditors employee

(c) Details of the valuation Report

5. An application has to be made for approval of the High Court for the scheme of arrangement

6. It is necessary that the Articles of Association should have the provision of reduction of it's Share Capital in any way, and its Memorandum of Association should provide for demerger, Division or split of the Company in any way. Demerger thus, resulting into reduction of companies share capital would also require the company to amend its Memorandum of Association.

\subsection{Compliance with SEBI Regulations}

The SEBI (Disclosure and Investor Protection) Guidelines do provide certain disclosures needed for protecting the investors. No specific guidelines are presently there. However, in SEBI Press Release 311-2003 dated December 17, 2003, it has been proposed by SEBI to enforce appropriate disclosures in case of demerger as in the case of amalgamation.

\subsection{Accounting for demerger}

In spite of lack of guidance in accounting standards, accounting for demerger is uniform across the globe, according to Asish K. Bhattacharyya, professor of finance and control, IIM-Calcutta. Neither the International Financial Reporting Standards (IFRS)-3- 'Business Combinations' - nor AS-14-' has Accounting for Amalgamations' in India - specifically dealt with accounting for demergers. But accounting for demerger is quite simple as it does not result in a purchase or sale transaction but is just a division of an existing entity, the demerged company. There is no reason to restate the carrying amount of assets and liabilities. Therefore, demerger is accounted for at the recorded book values of the assets and liabilities transferred to the new entity. The face value of new shares has no economic significance. In a demerger, the new company issues shares to all shareholders of the demerged company without receiving cash. On issuance of shares by the new company, for all practical purposes the share of the demerged company is split into two shares.

In a demerger, a new company is formed and all the assets and liabilities of an undertaking of the demerged company are transferred to the new company. "This new company, which has an economic and legal identity separate from the demerged company, issues shares to shareholders of the demerged company. As a result, a substantial number of shareholders of the demerged company become shareholders of the new company. 


\subsection{Reasons for Demerger Decisions}

Several studies have empirically analyzed the sources of shareholder gains around spin-off. These include Hue and Owers (1983), Miles and Rosenfeld (1983), Schipper and Smith (1983), Cusatis, Miles. and Woolridge (1993), Seward and Walsh (1996), Daley, Mehrotra, and Sivakumar (1997), Parrino (1997), and Desai and Jam (1998). The potential sources of shareholder gains from spin-offs analyzed in these studies may be classified as follows:

(i) Transfer of wealth from bondholders to shareholders,

(ii) Tax and regulatory advantages.

(iii) Restructuring of incentive contracts,

(iv) Improved focus and elimination of negative synergies

Among these, the improved focus and elimination of negative synergies hypothesis is an explanation that has received broad empirical support. According to Thomas Kirchmaier (May 2003), at first sight, it is far from obvious how a 'simple' break-up of an organisation into smaller units would create value. "If there are no synergies between the parent and the subsidiary, the sum of the post-divestitures' cash flows would equal the combined cash flow had the two units remained as one". The value of two business units should be identical before and after a demerger, unless some positive or negative synergies exist that create or destroy value under a combined ownership structure.

A demerger is therefore a sensible option if negative synergies or diseconomies of scale exist that can be eliminated by separating the firm into two or more independent entities. Possible explanations for such a value creation are plentiful and can be broadly categorized into five different types, namely:

a.Dismantling of conglomerates: Historically, demergers were used to dismantle conglomerates after it became apparent that the costs of running such organizational structures outweighed the benefits in the economic environment. The 'dismantling of conglomerates' argument is widely based on the idea of removing inefficient organizational structures and hence the elimination of negative synergies.

b.Organizational improvements: From an organizational perspective, value can be created through the elimination of misfits in the strategic focus or organizational properties of the organisation. In addition, the reduction of the size of an organization leads to an over-proportional reduction in 'information losses' within the hierarchy.

c.Capital market improvements: More focused units might improve access to the capital market or attract a new set of investors, thereby eliminating barriers to growth from a capital market perspective. 
d.Corporate Governance improvements: Value creation through improvements in the role and function of the head office, improvements in the structuring of managerial incentives and more effective market based governance mechanisms due to increased transparency.

e.Bondholder expropriation: Value redistribution from bondholders to shareholders through a reduction of quality of the collateral provided (Hite and Owers, 1983).

\subsection{Shareholders' Wealth}

There are broadly two objectives of a finance manager, viz.,

i) Profit Maximisation; and

ii) Wealth Maximization

Profit is a basic need for any organization to survive and future growth but it should not be the sole objective of any finance manager. As in corporate form organization, shareholders, who are the real owners of the company, are different from management, so every manager should try maximizing their wealth.

Shareholders' wealth is the number of shares hold by a shareholder multiply by market price of one share. Mathematically,

\section{Shareholders' wealth $=$ No. of shares $\mathbf{x}$ Market price per share}

Market price of a share also acts as a barometer of the company's performance. Therefore, a finance manger should try to increase the market price of their company's share in long run.

\subsection{Disadvantages of De-Merger}

Normally, mergers create synergy through cross-selling services, opening new markets, creating stronger brand identity, absorbing excess capacity and eliminating redundant costs. All of these require change and commitment. Discussing the potential for that commitment and investment to end in a de-merger is not conducive to an effective team-building environment. The easier it is to unwind the merger, the less likely the parties will be to work out their differences and keep the firms together.

Firms surviving a de-merger are likely to be, at least for some time, weaker than they were before the merger. In extreme cases, viability of one or both firms may be at stake.

\subsection{Selection of Topic}

It is not unusual to see a company separating one of its divisions into a new entity and getting a nod in the stock market for its action. The share price goes up and the shareholders gain, thus vindicating the decision. This keeps happening in USA, Europe and Japan. 


\section{Macrothink

In the last six years there have been a number of such actions in India which come under the umbrella of the synonyms of demergers, spin-offs, carve-outs, and so on.

The basic premise here is that, parts of the company get a better valuation than the single entity. The issue now is whether or not this can be a workable strategic proposition: Can we get superior valuations from demergers? Hence the present study was conducted under the title "Impact of demergers on shareholders' wealth".

\subsection{Scope of Study}

The scope of the study is confined to those companies which filed their Scheme of Demerger with Registrar of Companies during the calendar year 2006 i.e. $1^{\text {st }}$ January 2006 to $31^{\text {st }}$ December 2006. Either demerged or resulting companies which merged with other companies under the same scheme of their demerger are not considered in the study.

\subsection{Objective of study}

To study the impact of demerger on the shareholders' wealth with special reference to companies that demerged in India during the calendar year 2006.

\subsection{Hypothesis of the study}

The null hypothesis $\left[\mathrm{H}_{01}\right]$ considered for the study is "There is no significant difference between the shareholders' wealth before demerger and shareholders' wealth after demerger."

\subsection{Methodology of the study}

1.Population: All the firms which are listed with Bombay Stock Exchange and filed their Scheme of Demerger with Registrar of Companies and allot the shares of the resulting company to the shareholders during the calendar year 2006 i.e. $1^{\text {st }}$ January 2006 to $31^{\text {st }}$ December 2006. Either demerged or resulting companies which merged with other companies under the same scheme of their demerger are not considered in the study.

2.Sample Unit: The companies going for the demerger have been considered as sample unit for the study.

3.Sample size: 5 companies were taken as the sample for the study on the random sampling basis.

4.Research design adopted: Given the sampling unit and sampling design natural corollary is case study method of analysis. Hence six cases were considered, namely:

i. Television Eighteen India Limited

ii. Great Eastern Shipping Company Limited

iii. Zee Entertainment Enterprise Limited

iv. Camlin India Limited 


\section{Macrothink}

v. Indiabulls Financial Services

5.Data collection design: Data regarding details of demergers of companies has been extracted from the official websites of respective companies and official website of Bombay Stock Exchange. Data regarding prices of shares of various companies is extracted from official website of Bombay Stock Exchange.

\section{Analysis design}

i. The proportion of allocation of the shares in the resulting company in accordance with the number of shares held by members in the parent company (Pre-demerger state).

ii. Restructure of the capital (both quantity and face value), if any, in the parent company.

iii. The average pre-demerger share price has been taken as the average of the share price for six months immediately preceding the eligibility date (The date on which shareholders should hold the share of the demerged company to become eligible to receive the shares of resulting company as per scheme of demerger.)

iv. The average post-demerger share price of the demerged company has been taken as the average of the share price of the demerged company for six months or till 31 st July 2007 whichever of the two is earlier, immediately succeeding the eligibility date.

$\mathrm{v}$. The average post-demerger share price of the resulting companies has been taken as the average of the share price of the resulting company for six months or till $31^{\text {st }}$ July 2007 whichever of the two is earlier, from the listing date in Bombay Stock Exchange. The reason for considering the prices upto $31^{\text {st }}$ July is because the study was done in the month of August.

vi. The Shareholders' wealth in pre-demerged state has been calculated by multiplying the shares held by the members with that of the average share price in the pre-demerger state.

vii. The Shareholders' wealth in post-demerged state of the demerged company has been calculated by multiplying the shares held by the members in the demerged company with that of the average share price of the demerged company in the post-demerger state.

viii. The Shareholders' wealth in post-demerged state of the resulting companies has been calculated by multiplying the shares held by the members in the resulting company with that of the average share price of the resulting companies in the post-demerger state.

ix. The total Shareholders' wealth in the post-demerger state is the total of the shareholders' wealth in the demerged and resulting companies.

x. Comparison has been made between the shareholders' wealth in the pre \& post demerger state and percentage thereon has been calculated. 


\section{Macrothink Institute ${ }^{T M}$}

\subsection{Assumptions of the Study}

In the present study, a hypothetical case of a shareholder holding 100 shares in each of the demerging companies has been considered. The hypothetical case is considered so as to neutralize the effect of ESOPs, bonus shares or any other act which may result in change of equity share capital of the company after completion of demerger process.

\subsection{CASE-1 TELEVISION EIGHTEEN INDIA LIMITED}

Demerged Company : Television Eighteen India Limited

Resulting Company : Network 18 Fincap Limited

Effective Date $: 27^{\text {th }}$ September 2006

Scheme of Demerger :

The shareholders will get the Equity shares of the Resulting Company i.e. Network 18 Fincap Limited in the ratio of 12 equity shares of Rs 5/- each for every 10 shares of Rs.10/- each held by them in the Company. Subsequently, 14 equity shares of Rs.5/- each of Television Eighteen India Limited will be issued in lieu of every 10 equity shares of Rs. 10/- each held by the members of the Company.

Eligibility Date $\quad$ : $24^{\text {th }}$ November 2006

Shareholders' Wealth:

Table-1A

Pre-Demerger: Shareholders' Wealth in Television Eighteen India Limited

\begin{tabular}{|l|l|l|l|}
\hline \multicolumn{1}{|c|}{ Company } & $\begin{array}{c}\text { Equity } \\
\text { Shares }\end{array}$ & $\begin{array}{c}\text { Average pre-demerger } \\
\text { Share Price }\end{array}$ & $\begin{array}{c}\text { Shareholders' } \\
\text { Wealth }\end{array}$ \\
\hline $\begin{array}{l}\text { Television Eighteen India } \\
\text { Limited }\end{array}$ & 100 & Rs. 616.61 & Rs. 61661.00 \\
\hline
\end{tabular}

Source: Compiled from the data collected

Table-1B

Post-Demerger: Shareholders' Wealth in Television Eighteen India Limited

\begin{tabular}{|l|l|l|l|}
\hline \multicolumn{1}{|c|}{ Company } & $\begin{array}{c}\text { Equity } \\
\text { Shares }\end{array}$ & \multicolumn{1}{|c|}{$\begin{array}{c}\text { Average post-demerger } \\
\text { Share Price }\end{array}$} & \multicolumn{1}{|c|}{$\begin{array}{c}\text { Shareholders' } \\
\text { Wealth }\end{array}$} \\
\hline $\begin{array}{l}\text { Television Eighteen } \\
\text { India Limited }\end{array}$ & 140 & Rs. 639.20 & Rs. 89488.00 \\
\hline $\begin{array}{l}\text { Network } 18 \quad \text { Fincap } \\
\text { Limited }\end{array}$ & 120 & Rs. 432.97 & Rs. 51956.40 \\
\hline \multicolumn{2}{|l|}{ Total Shareholders' Wealth After Demerger } & Rs. 141444.40 \\
\hline
\end{tabular}

Source: Compiled from the data collected

From Table-1A and 1B, it is seen that there has been increase in the shareholders' wealth of Television Eighteen India Limited after demerger by $129.39 \%$. 


\subsection{CASE-2: GREAT EASTERN SHIPPING COMPANY LIMITED}

Demerged Company : Great Eastern Shipping Company Limited

Resulting Company : Great Offshore Limited

Effective Date $: 16^{\text {th }}$ October, 2006

Scheme of Demerger :

The shareholders will get the Equity shares of the Resulting Company i.e. Great Offshore Ltd in the ratio of 1 equity share of Rs 10/- each credited as fully paid-up in cash for every 5 equity shares of Rs 10/- each held by the members of the Company. Subsequently 5 Equity shares of the Company shall be reduced to 4 Equity shares of Rs 10/- each.

Eligibility Date : $8^{\text {th }}$ November 2006

Shareholders' Wealth:

Table-2A

Pre-Demerger: Shareholders' Wealth in Great Eastern Shipping Company Limited

\begin{tabular}{|c|c|c|c|}
\hline Com & $\begin{array}{l}\text { Equity } \\
\text { Shares }\end{array}$ & $\begin{array}{c}\text { Average pre-demerger } \\
\text { Share Price }\end{array}$ & $\begin{array}{c}\text { Shareholders' } \\
\text { Wealth }\end{array}$ \\
\hline $\begin{array}{l}\text { Great Eastern Shipping } \\
\text { Company Limited }\end{array}$ & 100 & Rs. 256.36 & Rs. 25636.00 \\
\hline
\end{tabular}

Source: Compiled from the data collected

Table-2B

Post-Demerger: Shareholders' Wealth in Great Eastern Shipping Company Limited

\begin{tabular}{|l|l|l|l|}
\hline \multicolumn{1}{|c|}{ Company } & $\begin{array}{l}\text { Equity } \\
\text { Shares }\end{array}$ & $\begin{array}{c}\text { Average post-demerger } \\
\text { Share Price }\end{array}$ & $\begin{array}{c}\text { Shareholders' } \\
\text { Wealth }\end{array}$ \\
\hline $\begin{array}{l}\text { Great Eastern Shipping } \\
\text { Company Limited }\end{array}$ & 80 & Rs. 209.41 & Rs. 16752.50 \\
\hline Great Offshore Ltd & 20 & Rs. 703.81 & Rs. 14076.50 \\
\hline \multicolumn{2}{|l|}{ Total Shareholders' Wealth After Demerger } & Rs. 30829.00 \\
\hline
\end{tabular}

Source: Compiled from the data collected

From Table-2A and 2B, it is seen that there has been increase in the shareholders' wealth of Great Eastern Shipping Company after demerger by $20.26 \%$.

\subsection{CASE-3: ZEE ENTERTAINMENT ENTERPRISE LIMITED}

Demerged Company $\quad$ : Zee Entertainment Enterprise Limited

Resulting Company : Zee News Limited

: Wire and Wireless India Limited

Effective Date $: 22^{\text {nd }}$ November 2006

Scheme of Demerger :

Shareholders of the Company received 45 shares of Zee News Limited and 50 shares of Wire 


\section{Macrothink}

and Wireless India Limited for every 100 shares held in the Company.

Eligibility Date $\quad: 16^{\text {th }}$ December 2006

Shareholders' Wealth:

Table-3A

Pre-Demerger: Shareholders' Wealth in Zee Entertainment Enterprise Limited

\begin{tabular}{|l|l|l|l|}
\hline \multicolumn{1}{|c|}{ Company } & $\begin{array}{c}\text { Equity } \\
\text { Shares }\end{array}$ & $\begin{array}{c}\text { Average pre-demerger } \\
\text { Share Price }\end{array}$ & $\begin{array}{c}\text { Shareholders' } \\
\text { Wealth }\end{array}$ \\
\hline $\begin{array}{l}\text { Zee Entertainment } \\
\text { Enterprise Limited }\end{array}$ & 100 & Rs. 291.72 & Rs. 29172.00 \\
\hline
\end{tabular}

Source: Compiled from the data collected

Table-3B

Pre-Demerger: Shareholders' Wealth in Zee Entertainment Enterprise Limited

\begin{tabular}{|l|l|l|l|}
\hline \multicolumn{1}{|c|}{ Company } & $\begin{array}{l}\text { Equity } \\
\text { Shares }\end{array}$ & \multicolumn{1}{|c|}{$\begin{array}{c}\text { Average post-demerger } \\
\text { Share Price }\end{array}$} & $\begin{array}{c}\text { Shareholders' } \\
\text { Wealth }\end{array}$ \\
\hline $\begin{array}{l}\text { Zee Entertainment } \\
\text { Enterprise Limited }\end{array}$ & 100 & Rs. 277.09 & Rs. 27709.00 \\
\hline $\begin{array}{l}\text { Wire and Wireless India } \\
\text { Limited }\end{array}$ & 50 & Rs. 89.11 & Rs. 4455.50 \\
\hline Zee News Limited & 45 & Rs. 40.32 & Rs. 1814.40 \\
\hline \multicolumn{2}{|l|}{ Total Shareholders' Wealth After Demerger } & Rs. 33978.90 \\
\hline
\end{tabular}

Source: Compiled from the data collected

From Table-3A and 3B, it is seen that there has been increase in the shareholders' wealth of Zee Entertainment Enterprise Limited after demerger by $16.48 \%$.

\subsection{CASE-4: CAMLIN LIMITED}

Demerged Company : Camlin Limited

Resulting Company : Camlin Fine Chemical Limited

Effective Date $: 17^{\text {th }}$ December 2006

Scheme of Demerger :

The shareholders will get the Equity shares of the Resulting Company i.e. Camlin Fine Chemicals Limited in the ratio of 1 equity share each credited as fully paid-up in cash for every 1 equity share each held by the members of the Company.

Eligibility Date $\quad: 19^{\text {th }}$ February 2007

Shareholders' Wealth: 
Table-4A

Pre-Demerger: Shareholders' Wealth in Camlin Limited

\begin{tabular}{|l|l|l|l|}
\hline \multicolumn{1}{|c|}{ Company } & $\begin{array}{c}\text { Equity } \\
\text { Shares }\end{array}$ & $\begin{array}{c}\text { Average pre-demerger } \\
\text { Share Price }\end{array}$ & $\begin{array}{c}\text { Shareholders' } \\
\text { Wealth }\end{array}$ \\
\hline Camlin Limited & 100 & Rs. 186.91 & Rs. 18691.00 \\
\hline
\end{tabular}

Source: Compiled from the data collected

Table-4B

Post-Demerger: Shareholders' Wealth in Camlin Limited

\begin{tabular}{|l|l|l|l|}
\hline \multicolumn{1}{|c|}{ Company } & $\begin{array}{c}\text { Equity } \\
\text { Shares }\end{array}$ & $\begin{array}{c}\text { Average post-demerger } \\
\text { Share Price }\end{array}$ & $\begin{array}{l}\text { Shareholders' } \\
\text { Wealth }\end{array}$ \\
\hline Camlin Limited & 100 & Rs. 135.09 & Rs. 13509.00 \\
\hline $\begin{array}{l}\text { Camlin Fine Chemicals } \\
\text { Limited }\end{array}$ & 100 & Rs. 53.95 & Rs. 5395.00 \\
\hline \multicolumn{2}{|l|}{ Total Shareholders' Wealth After Demerger } & Rs. 18905.00 \\
\hline
\end{tabular}

Source: Compiled from the data collected

From Table-4A and 4B, it is seen that there has not been any significant difference in shareholders' wealth of Camlin Limited before and after the demerger as there has been increase in earnings of shareholders' wealth by $1.14 \%$.

\subsection{CASE-5: INDIABULLS FINANCIAL SERVICES LIMITED}

Demerged Company : Indiabulls Financial Services Limited

Resulting Company : Indiabulls Real Estate Limited

Effective Date $\quad: 20^{\text {th }}$ December 2006

Scheme of Demerger :

The shareholders will get the Equity shares of the Resulting Company i.e. Indiabulls Real Estate Limited in the ratio of 1 equity share each credited as fully paid-up in cash for every 1 equity share each held by the members of the Company.

Eligibility Date $\quad: 29^{\text {th }}$ December 2006

Shareholders' Wealth:

Table-5A

Pre-Demerger: Shareholders' Wealth in Indiabulls Financial Service Limited

\begin{tabular}{|l|l|l|l|}
\hline \multicolumn{1}{|c|}{ Company } & $\begin{array}{c}\text { Equity } \\
\text { Shares }\end{array}$ & \multicolumn{1}{c|}{$\begin{array}{c}\text { Average pre-demerger } \\
\text { Share Price }\end{array}$} & $\begin{array}{c}\text { Shareholders' } \\
\text { Wealth }\end{array}$ \\
\hline $\begin{array}{l}\text { Indiabulls Financial } \\
\text { Services Limited }\end{array}$ & 100 & Rs. 395.49 & Rs. 39549.00 \\
\hline
\end{tabular}

Source: Compiled from the data collected 
Table-5B

Post-Demerger: Shareholders' Wealth in Indiabulls Financial Service Limited

\begin{tabular}{|l|l|l|l|}
\hline \multicolumn{1}{|c|}{ Company } & $\begin{array}{l}\text { Equity } \\
\text { Shares }\end{array}$ & $\begin{array}{c}\text { Average post-demerger } \\
\text { Share Price }\end{array}$ & $\begin{array}{l}\text { Shareholders' } \\
\text { Wealth }\end{array}$ \\
\hline $\begin{array}{l}\text { Indiabulls Financial } \\
\text { Service Limited }\end{array}$ & 100 & Rs. 450.91 & Rs. 45091.00 \\
\hline $\begin{array}{l}\text { Indiabulls Real Estate } \\
\text { Limited }\end{array}$ & 100 & Rs. 382.25 & Rs. 38225.00 \\
\hline \multicolumn{2}{|l|}{ Total Shareholders' Wealth After Demerger } & Rs. 83316.00 \\
\hline
\end{tabular}

Source: Compiled from the data collected

From Table-5A and 5B, it is seen that there has been increase in the shareholders' wealth of Indiabulls Financial Services Limited after demerger by $110.67 \%$.

\subsection{Conclusion}

From the above study it is concluded that, the samples under study excluding Camlin Limited have shown significant difference in the shareholders' wealth before demerger and after demerger. In other words, shareholders' wealth has been appreciated corresponding to demerger. In $80 \%$ of the sample, there was negative synergy in their diversified business. Thus, due to demergers or spin-off the companies were successful in getting proper valuation of their various diversified businesses.

Presently de-mergers are creating enormous wealth for shareholders. However, Investors should differentiate between genuine attempts at value creation and de-mergers undertaken to create hype around the stocks. Stay away from dubious companies that want to manipulate prices. Investors should focus on the quality of management and corporate governance record of the company.

\subsection{Limitations of the study}

1. Difficulty in abstracting data.

2. Time period considered for the study can be considered one of the limitations of the study.

3. Size of the samples considered can also be considered as one the limitations of the study.

4. This study did not consider the impact of change in the business scenario of the companies before and after the demerger which may affect its share prices.

5. This project has been done in bullish market and thus, result may be differing in a bearish market.

\subsection{Scope of future research}

1. Study can be done where mergers and demergers have taken place simultaneously in a company. 


\section{Macrothink}

2. Study can be done using more samples and also from different years.

3. Study can be done on price fluctuation and various decisions taken by the company on demerger.

4. Study can be done taking into consideration the total share capital of the companies i.e. demerged and resulting companies.

\section{References}

\section{Books \& Journals}

1. Kothari C.R (2004). "Research Methodology-Methods and Techniques", $2^{\text {nd }}$ edition, New age International Publishers

2. Krishnaswami, S. and V. Subramaniam. (1999). "Information Asymmetry, Valuation, And The Corporate Spin-Off Decision”, Prentice hall of India

3. Sharma and Gupta. (2003). "Management Accounting", Kalyani Publishers, $4^{\text {th }}$ Edition

4. Thomas K. (2003). The Performance Effects of European Demergers, May 2003, Working Paper, Centre for Economic Performance.

\section{Websites}

5. Bombay Stock Exchange - BSE site for SENSEX, stock quotes and market trend, www.bseindia.com

6. www.camlin.com

7. www.greatship.com

8. www.indiabulls.com

9. Investment Strategy : Joys of separation, at, $\left(15^{\text {th }}\right.$ July 2007)

10. www.zeebusiness.com

11. www.moneycontrol.com

12. www.tv18online.com

13. Www. economictimes.indiatimes.com

14. www.zeetelevision.com

15. http://www.capitalmarket.com/cmedit/story11-43.asp? $\mathrm{SNo}=175119$ ", Investment strategy: Joys of Separation, accessed on 15-07-2007 at $1730 \mathrm{hrs}$.

16. http://www.thehindubusinessline.com/mentor/2007/06/04/stories/2007060400261200.h tm, retrieved on 1-10-2008 at $1800 \mathrm{hrs}$

17. http://www.thefreelibrary.com/Untying+the+knot:+planning+for+de-merger:+a+well-d rafted+agreement...-a0170815233 retrieved on 1-10-2008 at $1810 \mathrm{hrs}$ 